SAINS TANAH - Journal of Soil Science and Agroclimatology

Journal homepage: http://jurnal.uns.ac.id/tanah

\title{
Application of litters to inhibit nitrification in Vertisols on sweet corn (Zea mays S.)
}

\author{
Supriyadi $^{1 *}$, Adiprasetya Widyatama ${ }^{2}$, Gadis Mona Prinandhika ${ }^{2}$, Purwanto $^{1}$, Sri Hartati $^{1}$ \\ ${ }^{1}$ Department of Soil Science, Faculty of Agriculture, Sebelas Maret University, Indonesia \\ ${ }^{2}$ Undergraduate Program of Soil Science, Faculty of Agriculture, Sebelas Maret University, Indonesia
}

\section{ARTICLE INFO}

Keywords:

Ammonium

Nitrate

Potential nitrification

Actual nitrification

Efficiency

Article history

Submitted: 2020-08-10

Accepted: 2021-05-08

Available online: 2021-06-30

Published regularly: June 2021

* Corresponding Author

Email address:

supriyadi_uns@staff.uns.ac.id

\section{ABSTRACT}

Nitrification, or the process of oxidation of ammonium to nitrate in the soil, needs to be inhibited because it reduces the efficiency of nitrogen fertilizers. Vertisols have 2:1 minerals and have a high negative charge, so ammonium is more absorbed by soil particles, whereas nitrate is free to move in the soil and diffuses into the plant tissue or is leached with gravity water. This study aimed to determine the litter treatment that can inhibit the nitrification process in Vertisols on sweet corn plants. This research was conducted from June until November 2019 in the Greenhouse of Plesungan, Gondangrejo, Karanganyar, Indonesia. This study used a basic completely randomized design with a single factor (litter type) as an immobilizer. The types of litter used in this study were Gliricidia maculata, Albizia falcataria, Senna siamea, and Tithonia diversifolia. The parameters observed were ammonium content, potential nitrification, average nitrate content, actual nitrification, plant height, number of leaves, and plant dry weight. Tithonia diversifolia gave the highest actual nitrification of $23.26 \%$. Senna siamea has the lowest actual nitrification of $12.36 \%$, followed by Gliricidia maculata with $17.39 \%$ and Albizia falcataria with $17.67 \%$. This shows that the Tithonia diversifolia litter has the highest value in inhibiting nitrification. Sweet corn plants treated with the Tithonia diversifolia litter had the best plant growth compared to the other treatments. Therefore, among the treatments used, the Tithonia diversifolia litter was more optimal for inhibiting nitrification in Vertisols.
\end{abstract}

How to Cite: Supriyadi, Widyatama, A. Prinandhika, G. M., Purwanto, Hartati, S. (2021). Application of litters to inhibit nitrification in Vertisols on sweet corn (Zea mays S.) [Research]. Sains Tanah Journal of Soil Science and Agroclimatology, 18(1): 48-57. https://dx.doi.org/10.20961/stjssa.v18i1.43631

\section{Introduction}

Nitrification, or the process of oxidation of ammonium to nitrate in the soil, needs to be inhibited because it reduces the efficiency of nitrogen fertilizers. The application of excessive amounts of $\mathrm{N}$ fertilizer raises various problems, for example, the biochemical change from an immobilized nitrogen form, ammonium, to a more mobile form, nitrite or nitrate, by chemoautotroph bacteria during the nitrification process could be harmful to the environment (Purwanto et al., 2014). Nitrification is a critical step in the nitrogen cycle and has significant agricultural and environmental consequences for the availability of nitrogen as a plant nutrient (Yao et al., 2011). This process is highly detrimental to plants because it causes the efficient use of nitrogen by plants to decrease, thus limiting crop production. For sweet corn, for example, the absorption of nitrate requires energy of 20 ATP, whereas the absorption of ammonium needs 6
ATP. In the environment, nitrification also has a negative impact, because it produces $\mathrm{NO}_{3}{ }^{-}$, which is very dangerous when absorbed by plants. About $53 \%$ of $\mathrm{NO}_{3}{ }^{-}$easily leaches with groundwater, and through denitrification, $\mathrm{NO}_{3}{ }^{-}$is converted to $\mathrm{N}_{2} \mathrm{O}, \mathrm{NO}$, and $\mathrm{N}_{2}$ gases (Liu et al., 2014). The suppression of soil nitrification can be an important strategy for minimizing $\mathrm{N}$ losses from agricultural systems (Gong et al., 2013).

Nitrification is a more important source of $\mathrm{NO}$ and $\mathrm{N}_{2} \mathrm{O}$ than is denitrification when water-filled pore space (WFPS) is at $<60 \%$, and the reverse is true when WFPS is at $>60 \%$ (Macdonald et al., 2011). The nitrification activity after $\mathrm{N}$ fertilizer application is the main driver of $\mathrm{N}$ loss during the aerobic upland season because of nitrate leaching. Nitrification is also considered as an indirect driver of $\mathrm{N}$ loss during the flooded rice-growing season because the 
denitrification rate in flooded soil is controlled by the nitrification rate instead of the activities of denitrification enzymes (Lan et al., 2017). In environments unfavorable to autotrophic nitrifying bacteria, nitrification may result from the activity of heterotrophic microorganisms (Dolinšek et al., 2013) since ammonia-oxidizing bacteria are weaker competitors for ammonium than ammonia-assimilating heterotrophs when ammonium is limited (Faeflen et al., 2016).

The important factors that control soil $\mathrm{N}$ mineralization and nitrification include soil $\mathrm{C} / \mathrm{N}$ ratio (Urakawa et al., 2016), moisture and temperature ( $\mathrm{Yu}$ et al., 2010), fertilization (Zhang et al., 2015), vegetation and stand age (Nishizawa et al., 2016), and land-use change (Norton \& Ouyang, 2019). Nitrification inhibitors are chemicals that slow down the process of nitrification, i.e., the transformation of $\mathrm{NH}_{3}$ to nitrite. This slowdown in nitrification is due to the inhibition of the activities of the Nitrosomonas bacteria group, which transforms ammonium to nitrite; the formation of nitrate is thus slowed down. Leaching, as well as volatilization losses, are reduced because the nitrogen remains in the ammonium form (Ransom et al., 2020).

Within the $\mathrm{N}$ cycle, nitrification, the oxidation of ammonium to nitrate via an intermediate step that generates nitrite, is of exceptional interest as it modifies the relative availability of the two forms of ammonium and nitrate that are most readily available for plant $\mathrm{N}$ nutrition (Veresoglou, 2012). Nitrate leaching is followed by the leaching of base cations in the soil, thereby reducing base saturation and increasing soil acidity, which ultimately worsens the chemical nature of the soil (Goulding, 2016). In general, nitrification must be inhibited because nitrate that is leached into water bodies can cause eutrophication, which can reduce levels of dissolved oxygen, increase concentrations of greenhouse gases, and thus contribute to environmental pollution.

Vertisols are a type of soil that is dark gray to black, are clay textured, have slickenside, and have fractures that can periodically shrink and swell (Dudek et al., 2019). The composition of Vertisols is always dominated by type 2:1 clay minerals, particularly montmorillonite (Rajamuddin et al., 2013). Vertisols have relatively rich nutrient reserves, although they are not yet available for plants (Dudek et al., 2019). Soil Vertisols have a high negative charge, so ammonium is more absorbed by soil particles, whereas nitrate moves freely in the soil and diffuses into the plant tissue (Scherer et al., 2014). Ammonium content in Vertisols' stagnant soil water is lower than the nitrate because Vertisols has variable minerals that can adsorb ammonium and nitrate. This occurs because soil has a more negative charge so that more ammonium is absorbed by soil particles while $\mathrm{NO}_{3}{ }^{-}$is freer to move in the soil and diffuses into the plant tissue. The more problems in Vertisols management are on the physical properties rather than on the chemical properties. Its because Vertisols have relatively rich nutrient reserves, although they are not yet available for plants. The problems related to the physical properties of the soil are in the form of heavy clay texture, swelling and shrinking properties, low infiltration rates, and slow water drainage. Inhibition of nitrification offers the potential for decreasing soil nitrate losses via retarding the microbial transformation of soil ammonium to soil nitrate (Ruser \& Schulz, 2015). Efforts to inhibit nitrification and increase the utilization of nitrogen include maintaining the amount and diversity of litter input quality so that the immobilization of ammonium (nitrification substrate) and $\mathrm{O}_{2}$ competition between heterotrophic bacteria and nitrifying bacteria are increased (Wati et al., 2020). Inhibition of the nitrification process is done by adding litter as a natural nitrification inhibitor.

Nitrification inhibitor compounds are relatively expensive, no effective nitrification inhibitor compound has been found against the target of Nitrosomonas bacteria and nitrification inhibitor does not harm the non-target bodies (Purwanto \& Supriyadi, 2014). Efforts to inhibit nitrification are carried out by maintaining the amount and variety of the quality of litter input, it will increase ammonium immobilization (nitrifying substrate) and $\mathrm{O}_{2}$ competition between heterotrophic bacteria and nitrifying bacteria (Wati et al., 2020). Thus, in the present research, the process of nitrification in the soil is inhibited with the addition of litter as a natural nitrification immobilizer. The addition of litter is intended to reduce the concentration of $\mathrm{NO}_{3}{ }^{-}$in the soil so that there is competency in the use of ammonium and $\mathrm{NO}_{3}{ }^{-}$by heterotrophic microbes during the decomposition of organic matter. Previous research showed that low-quality litter decreased potential nitrification by $77.35 \%$ and high-quality litter decreased by 25.05\% (Wati et al., 2020). The types of litter used in this study are Gliricidia maculata, Albizia falcataria, Senna siamea, and Tithonia diversifolia. This study aims to determine the litter treatment that can inhibit the nitrification process in Vertisols on sweet corn plants.

\section{Material and Methods}

\subsection{Experimental Site and Soil Properties}

This research was conducted from June to November 2019 in the Greenhouse of Plesungan, Gondangrejo, Karanganyar. Laboratory analysis was carried out in the Chemistry and Soil Fertility Laboratory and the Soil Biology Laboratory in the Faculty of Agriculture, Sebelas Maret University, Surakarta. Vertisols as soil samples were taken from Jatikuwung, Gondangrejo, Karanganyar, Indonesia $\left(7^{\circ} 31^{\prime} 3^{\prime \prime} \mathrm{S}, 110^{\circ} 50^{\prime} 52^{\prime \prime} \mathrm{E}\right)$ used simple random purposive sampling, which was taken from a depth of $0-20 \mathrm{~cm}$. The soil was composited and dried. The pot size for each treatment was $35 \mathrm{~cm} \times 26 \mathrm{~cm}$. Ten kilograms of soil, with a volume of $22,759 \mathrm{~cm}^{3}$, was put in the pot.

Based on the results of the initial soil analysis, the chemical properties of Vertisols were as follows: $6.805 \mathrm{pH}$ $\mathrm{H}_{2} \mathrm{O}$, organic $\mathrm{C}$ of $0.869 \%$, organic matter content of $1.49 \%$, total $\mathrm{N}$ of $0.477 \%, \mathrm{C} / \mathrm{N}$ ratio of 1.82 , and moisture content of $7.77 \%$. The plant litter species used were Gliricidia maculata, Albizia falcataria, Senna siamea, and Tithonia diversifolia. These were chosen because they are easy to obtain, grow fast, have abundant biomass, and have varying content 
Table 1. Initial chemical characteristics of each litter

\begin{tabular}{clccccc}
\hline & & \multicolumn{4}{c}{ Chemical content } \\
\cline { 3 - 7 } No. & Litter type & $\begin{array}{c}\text { Carbon/nitrogen } \\
\text { ratio }\end{array}$ & $\begin{array}{c}\text { Lignin } \\
(\%)\end{array}$ & $\begin{array}{c}\text { Polyphenols (\%) } \\
\text { polyphenols/nitrogen }\end{array} \begin{array}{c}\text { Lignin + } \\
\text { quality } \\
\text { class }\end{array}$ \\
\hline 1 & Gliricidia maculata & 10.00 & 20.02 & 9.24 & 7.33 & High \\
2 & Albizia falcataria & 7.00 & 30.10 & 15.11 & 9.00 & High \\
3 & Senna siamea & 16.95 & 16.10 & 1.87 & High \\
4 & Tithonia diversifolia & 18.75 & 20.84 & 4.37 & 18.35 & Low \\
\hline
\end{tabular}

Note: Litter quality class is based on content (lignin + polyphenol)/nitrogen (Wati et al., 2020).

Table 2. ANOVA test of parameters affected by various types of litter for 30 days on Vertisols and plant growth

\begin{tabular}{lc}
\hline \multicolumn{1}{c}{ Parameter } & $\begin{array}{c}\text { p-value } \\
\text { (Significance) }\end{array}$ \\
\hline Ammonium & 0.011 \\
Nitrate & $<0.001$ \\
Potential nitrification & 0.002 \\
Actual nitrification & 0.538 \\
Organic C & 0.080 \\
Total N & 0.921 \\
C/N ratio & 0.175 \\
pH H & $\mathrm{O}$ \\
Plant height & 0.006 \\
Number of leaves & 0.991 \\
\hline
\end{tabular}

quality (polyphenol, lignin, and $\mathrm{C} / \mathrm{N}$ ratio), thus causing the results in terms of the inhibition of nitrification to vary also. These plants were air-dried and then mashed and filtered with a sieve having a diameter of $0.5 \mathrm{~mm}$. There were five treatments, namely, G1 (control treatment), G2 (Gliricidia maculata), G3 (Albizia falcataria), G4 (Senna siamea), and G5 (Tithonia diversifolia), with a completely randomized design variable approach consisting of one factor with three replications.

\subsection{Crop Management and Treatments}

Each type of litter with a dry weight of $28.125 \mathrm{~g} \mathrm{pot}^{-1}$ was immersed and mixed evenly with the soil in the pot. Litter was given 5 days of incubation before sweet corn seeds were planted. $\left(\mathrm{NH}_{4}\right)_{2} \mathrm{SO}_{4}$ fertilizer with a dose equivalent to $200 \mathrm{~kg}$ $\mathrm{ha}^{-1}$ was given in the appropriate form of treatment (Tabri et al., 2018). Basic fertilization with the manure of $200 \mathrm{t} \mathrm{ha}^{-1}$, or equivalent to $8 \mathrm{~g} \mathrm{pot}^{-1}$, was carried out. SP-36 fertilizer with a dose of $147 \mathrm{~kg} \mathrm{ha}^{-1}$, or equivalent to $0.735 \mathrm{~g} \mathrm{pot}^{-1}$, and $\mathrm{KCl}$ fertilizer at a dose of $100 \mathrm{~kg} \mathrm{ha}^{-1}$, or equivalent to $0.5 \mathrm{~g} \mathrm{pot}^{-1}$, were prepared (Sofyan et al., 2019). SP-36 and $\mathrm{KCl}$ fertilizers were added 5 days after incubation or together with the planting of sweet corn seeds. Three sweet corn seeds were planted in each pot, and after a week, one sweet corn plant grew in each pot. Potential nitrification measurements were carried out on $0,6,12,18,24$, and 30 days after planting. Soil samples were taken every 5 days around the roots of the sweet corn plant. Harvesting was done at the age of about 50 days or in the vegetative phase of the plant. The parameters observed were plant height, number of leaves, and plant weight.

Soil samples were analyzed for organic C, total N, C/N, and $\mathrm{pH}$, measurements on $0,6,12,18,24$, and 30 days after planting. The electrometric $\mathrm{pH}$ measurement method (using a $\mathrm{pH}$ meter), using air-dried soil (a diameter of $0.5 \mathrm{~mm}$ and a weight of $10 \mathrm{~g}$ ), was used to measure the actual $\mathrm{pH}$ using $\mathrm{H}_{2} \mathrm{O}$. According to an analysis of organic $\mathrm{C}$ using the Walkley and Black method, carbon as an organic compound can reduce the orange $\mathrm{Cr}_{6}{ }^{+}$to the green $\mathrm{Cr}_{3}{ }^{+}$in an acidic atmosphere. The intensity of the green color formed is equivalent to that of the carbon content and can be measured by a spectrophotometer at a wavelength of $561 \mathrm{~nm}$. Analysis of organic $\mathrm{C}$ using $0.5 \mathrm{~mm}$ air-dried soil, $1 \mathrm{~N} \mathrm{~K}_{2} \mathrm{Cr}_{2} \mathrm{O}_{7}$, concentrated $\mathrm{H}_{2} \mathrm{SO}_{4}$, standard solution $5000 \mathrm{ppm} \mathrm{C}$. Total $\mathrm{N}$ of soil, analyzed using the Kjeldahl method, in the form of organic nitrogen compounds was oxidized in a concentrated sulfuric acid environment with a catalyst mixture of selen to form $\left(\mathrm{NH}_{4}\right)_{2} \mathrm{SO}_{4}$. The ammonium content in the extract was determined by distillation. In the distillation method, the extract is alkalized by adding $\mathrm{NaOH}$ solution. Furthermore, the liberated $\mathrm{NH}_{3}$ was bound by boric acid and trapped with a standard solution of $\mathrm{H}_{2} \mathrm{SO}_{4}$ using a Conway pointer. Total $\mathrm{N}$ of soil using air-dried soil $0.5 \mathrm{~mm}$, concentrated $\mathrm{H}_{2} \mathrm{SO}_{4}, \mathrm{CuSO}_{4}$, and $\mathrm{K}_{2} \mathrm{SO}_{4}$, Aquadest, $\mathrm{H}_{2} \mathrm{SO}_{4} 0.1 \mathrm{~N}$ or $\mathrm{H}_{2} \mathrm{BO}_{4} 10 \%$, Indicator Methyl red, $\mathrm{NaOH} 0.1 \mathrm{~N}$ or $\mathrm{NCl} 0.1 \mathrm{~N}$ and Zn Grains. The $\mathrm{C} / \mathrm{N}$ ratio was obtained by dividing the organic carbon content by the total $\mathrm{N}$ of soil.

\subsection{Litter Quality}

Table 1 presents the content of $\mathrm{C} / \mathrm{N}$, lignin, polyphenols, and (lignin + polyphenol) $/ \mathrm{N}$ and litter quality classes. Highquality litter is litter that has a $\mathrm{C} / \mathrm{N}$ ratio of $<20$ or a (lignin + polyphenol)/N ratio of $<10$. Gliricidia maculata has a (lignin + polyphenol)/N ratio of 7.33; Albizia falcataria, 9; Senna siamea, 6.83; and Tithonia diversifolia, 18.35. These results indicate that Tithonia diversifolia is a low-quality litter, whereas Gliricidia maculata, Albizia falcataria, and Senna siamea are high-quality litter types.

\subsection{Measurement of Potential Nitrification, Ammonium, and Nitrate}

Potential nitrification was measured using the Berg and Rosswall method from the amount of $\mathrm{NO}_{2}^{-}$, which was formed from soil samples after being added with $\left(\mathrm{NH}_{4}\right)_{2} \mathrm{SO}_{4}$ and incubated at $25^{\circ} \mathrm{C}$ for $5 \mathrm{~h}$ (Ward, 2011). The formed nitrite was extracted with $\mathrm{KCl}$ and measured colorimetry at $520 \mathrm{~nm}$. The oxidation process of $\mathrm{NO}_{2}^{-}$to $\mathrm{NO}_{3}{ }^{-}$during incubation was 
inhibited by the addition of $\mathrm{NaClO}_{3}$. The calculation for potential nitrification was carried out using Formula [1].

$\frac{(S-C) 25 \times 1 \times 1000 \times 100}{5 \times 5 \% d m}=n g N \frac{1}{g} d m \frac{h}{5}$

where $\mathrm{S}$ is the average sample value $(\mathrm{mg} \mathrm{N}), \mathrm{C}$ denotes the control value $(\mathrm{mg} \mathrm{N}), 25 \times 1$ indicates the extract volume $(\mathrm{ml}), 1000$ is the conversion factor ( $1 \mathrm{mg} \mathrm{N}=1000 \mathrm{ng} \mathrm{N}), 5$ is the aliquot filtrate value $(\mathrm{g}), 5$ is the original soil weight $(\mathrm{g})$, and $100 \%^{-1} \mathrm{dm}$ is the factor for soil dry matter.

Ammonium in the soil can be measured directly by colorimetry using the indophenol blue method (Ngibad, 2019) and using Formula [2].

Concentration of ammonium ( $\mathrm{mg} \mathrm{N} \mathrm{kg}^{-1}$ ) = ppm curve/ew $\mathrm{N} x \mathrm{df}$....[2]

where ppm curve indicates the sample levels obtained from the relationship curve between the standard series levels with their readings after being corrected by a blank solution, ew denotes the equivalent weight, $\mathrm{N}$ is 14 , and $\mathrm{df}$ denotes the dilution factor (if any).

Nitrates in the soil can be measured spectrophotometrically using brucine dye reagents (Iklima AS et al., 2019) and using Formula [3].

Concentration of nitrate $\left(\mathrm{mg} \mathrm{N} \mathrm{kg}^{-1}\right)=\mathrm{ppm}$ curve/ew $\mathrm{N} \mathrm{x} \mathrm{df}$

where ppm curve means the sample levels obtained from the relationship curve between the standard series levels with their readings after being corrected by a blank solution; ew denotes the equivalent weight, $\mathrm{N}$ is 14 , and df denotes dilution factor (if any).

\subsection{Statistical Analysis}

The data were analyzed using ANOVA with $\alpha=5 \%$ and $1 \%$, followed by the Duncan multiple range tests, to determine statistically significant differences between treatments, and Pearson's correlation test to determine the relationship between parameters. Data analysis was performed using IBM SPSS Statistics 24 software.

\section{Results}

\subsection{Ammonium}

Table 2 shows the ANOVA test results of parameters affected by various litter types for 30 days on Vertisol and plant growth. The modified treatment affected the concentration of ammonium in the soil ( $p=0.011$ ) (Table 2$)$. Ammonium concentration and the average ammonium concentration are presented in Figure $1 \mathrm{a}$ and Figure 2a, respectively. Ammonium concentration experienced dynamics during the 30 days of observation. The dynamics on day 0 to day 6 indicate that all treatments experienced a decrease in ammonium concentration; for 12 days after day 6. Tithonia diversifolia and Senna siamea treatments experienced an increase and other treatments experienced a decrease in ammonium concentration (Figure 1a).

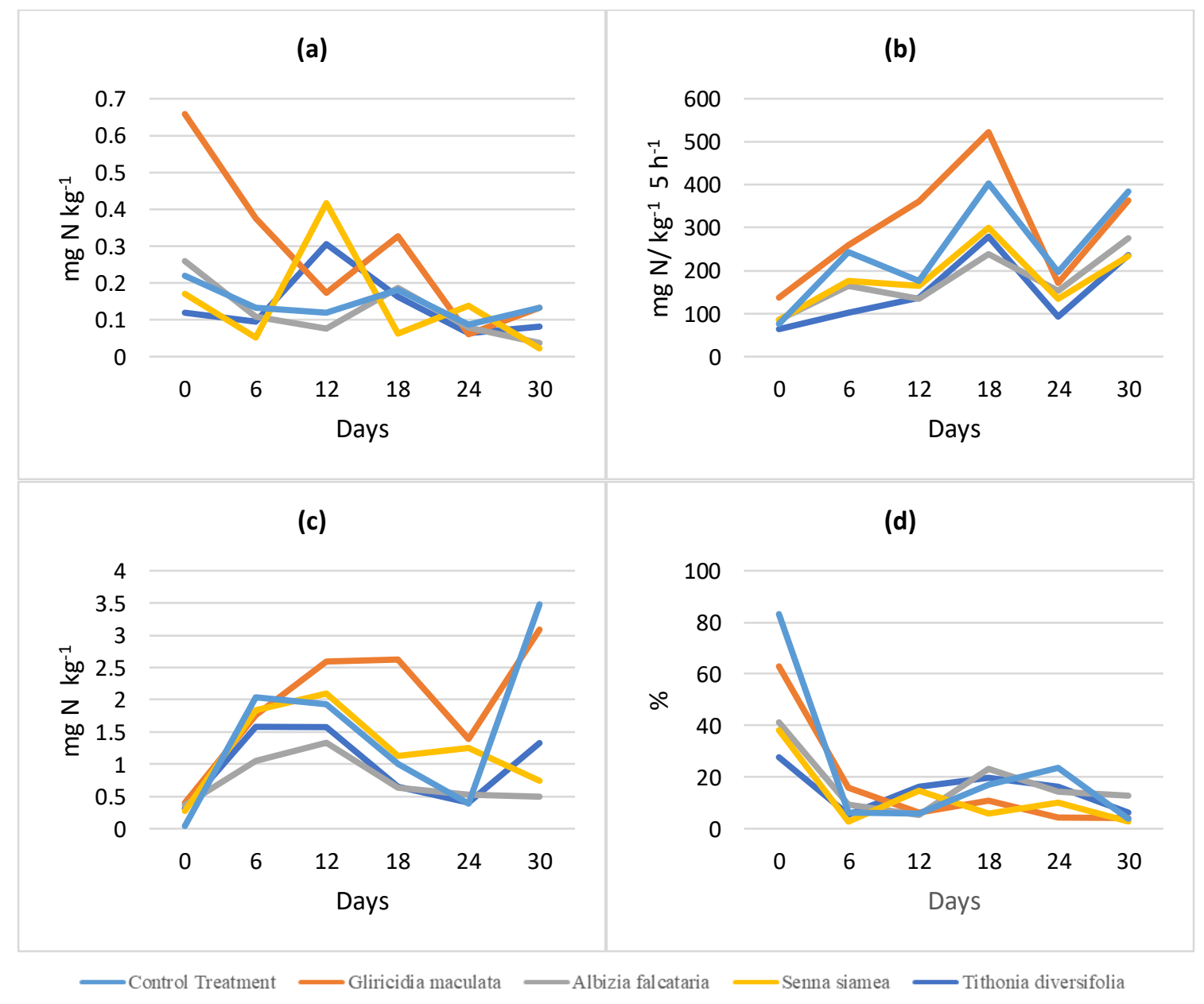

Figure 1. Dynamics of (a) ammonium, (b) potential nitrification, (c) nitrate, and (d) actual nitrification for 30 days. 
Table 3. Pearson's correlation ( $r$ ) between parameters

\begin{tabular}{|c|c|c|c|c|c|c|c|c|c|c|}
\hline Correlations & Ammonium & Nitrate & $\begin{array}{c}\text { Potential } \\
\text { Nitrification }\end{array}$ & $\begin{array}{c}\text { Actual } \\
\text { nitrification }\end{array}$ & $\begin{array}{c}\text { C } \\
\text { organic }\end{array}$ & Total N & $\mathrm{C} / \mathrm{N}$ & $\mathrm{pH}$ & $\begin{array}{l}\text { Plant } \\
\text { height }\end{array}$ & $\begin{array}{c}\text { Number } \\
\text { of } \\
\text { leaves }\end{array}$ \\
\hline Ammonium & 1 & 0.044 & 0.098 & $0.539^{* *}$ & $-0.256^{*}$ & $-0.344^{* *}$ & 0.087 & 0.143 & $-0.335^{* *}$ & $-0.309^{* *}$ \\
\hline Nitrate & 0.044 & 1 & $0.516^{* *}$ & $-0.567^{* *}$ & 0.171 & 0.048 & 0.028 & 0.091 & 0.204 & $0.412^{* *}$ \\
\hline $\begin{array}{l}\text { Potential } \\
\text { Nitrification }\end{array}$ & 0.098 & $0.516^{* *}$ & 1 & $-0.322^{* *}$ & $0.249^{*}$ & 0.114 & -0.027 & 0.077 & $0.404^{* *}$ & $0.388^{* *}$ \\
\hline $\begin{array}{l}\text { Actual } \\
\text { nitrification }\end{array}$ & $0.539^{* *}$ & $-0.567^{* *}$ & $-0.322^{* *}$ & 1 & $-0.384^{* *}$ & $-0.315^{* *}$ & 0.034 & 0.078 & $-0.518^{* *}$ & $-0.612^{* *}$ \\
\hline Corganic & $-0.256^{*}$ & 0.171 & $0.249^{*}$ & $-0.384^{* *}$ & 1 & $0.735^{* *}$ & -0.141 & $-0.351^{* *}$ & $0.754^{* *}$ & $0.734^{* *}$ \\
\hline Total N & $-0.344^{* *}$ & 0.048 & 0.114 & $-0.315^{* *}$ & $0.735^{* *}$ & 1 & $-0.585^{* *}$ & $-0.523^{* *}$ & $0.744^{* *}$ & $0.738^{* *}$ \\
\hline $\mathrm{C} / \mathrm{N}$ & 0.087 & 0.028 & -0.027 & 0.034 & -0.141 & $-0.585^{* *}$ & 1 & $0.238^{*}$ & $-0.299^{* *}$ & $-0.302^{* *}$ \\
\hline $\mathrm{pH}$ & 0.143 & 0.091 & 0.077 & 0.078 & $-0.351^{* *}$ & $-0.523^{* *}$ & $0.238^{*}$ & 1 & -0.198 & $-0.248^{*}$ \\
\hline Plant height & $-0.335^{* *}$ & 0.204 & $0.404^{* *}$ & $-0.518^{* *}$ & $0.754^{* *}$ & $0.744^{* *}$ & $-0.299^{* *}$ & -0.198 & 1 & $0.880^{* *}$ \\
\hline $\begin{array}{l}\text { Number of } \\
\text { leaves }\end{array}$ & $-0.309^{* *}$ & $0.412^{* *}$ & $0.388^{* *}$ & $-0.612^{* *}$ & $0.734^{* *}$ & $0.738^{* *}$ & $-0.302^{* *}$ & $-0.248^{*}$ & $0.880^{* *}$ & 1 \\
\hline
\end{tabular}

Remarks: ${ }^{* *}$ Correlation is significant at $\alpha=0.01$; $^{*}$ Correlation is significant at $\alpha=0.05$

The treatment of Tithonia diversifolia and Senna siamea at day 18 , showed a decrease in ammonium concentration, but the other treatments showed an increase in ammonium concentration. On day 24, all treatments showed that ammonium concentration decreased, except for Senna siamea. At day 30, the treatment of Gliricidia maculata and Tithonia diversifolia had an increase in ammonium concentration, and other treatments had a decrease. For 30 days, the average ammonium concentration kept decreasing (Figure 2a). The Gliricidia maculata treatment had the highest ammonium concentration of $0.288 \mathrm{mg} \mathrm{N} \mathrm{kg}^{-1}$, and the Albizia falcataria treatment had the lowest of $0.124 \mathrm{mg} \mathrm{N} \mathrm{kg}^{-1}$. Ammonium has a significantly positive correlation with actual nitrification ( $r=0.539$ ) (Table 3$)$.

\subsection{Potential Nitrification}

The treatment modification significantly affected the potential nitrification in the soil $(p=0.002)$ (Table 2). The potential nitrification and its average are presented in Figure $1 b$ and Figure $2 b$, respectively. The potential nitrification from day 0 to day 6 increased in all treatments and decreased except for Gliricidia maculata and the control treatment at day 12 (Figure $1 \mathrm{~b}$ ). On day 18, the potential nitrification in all treatments increased, and then it decreased at day 24 and again increased at day 30 . The Gliricidia maculata treatment has the highest potential nitrification of $302.52 \mathrm{mg} \mathrm{N} \mathrm{kg}^{-1} 5 \mathrm{~h}^{-1}$, and the control treatment has the lowest of $152.05 \mathrm{mg} \mathrm{N} \mathrm{kg}^{-1}$ $5 \mathrm{~h}^{-1}$ (Figure 2b). Potential nitrification was positively correlated with nitrate $(r=0.516)$ (Table 3$)$.

\subsection{Nitrate}

The treatments significantly affected the concentration of nitrates in the soil $(p<0.01)$ (Table 2). Nitrate concentration and its average are presented in Figure $1 c$ and Figure 2c, respectively. Nitrate concentration from day 0 to day 6 experienced a rapid increase in all treatments (Figure 1c). This is due to the formation of nitrate at day 0 . Concentration nitrate on control and Tithonia diversifolia, from day 6 to 12 were decreased but in the other treatments were increased. On day 18 , the nitrate concentration of all treatments was decreased, except the Gliricidia maculata. On day 24, all treatments had a decrease nitrate concentration, except the Senna siamea, and on day 30, the treatment of Senna siamea and Albizia diversifolia showed a decreased nitrate concentration, whereas the other treatments had an increased nitrate concentration. The Gliricidia maculata treatment had the highest nitrate of $1.975 \mathrm{mg} \mathrm{N} \mathrm{kg}^{-1}$, and the Albizia falcataria treatment had the lowest nitrate of 0.735 $\mathrm{mg} \mathrm{N} \mathrm{kg}^{-1}$ (Figure 2c). Nitrate has a significant correlation with potential nitrification $(r=0.516)$ and actual nitrification ( $r=-0.567)$ (Table 3).

\subsection{Actual Nitrification}

Treatment had no significant effect on the actual nitrification ( $p=0.538$ ) (Table 2). The actual concentration and its average are presented in Figure $1 d$ and Figure $2 d$, respectively. The mean of actual nitrification of all treatments was highest at 0 day incubation time, and then it decreased at sixth days incubation. Some experienced an increase and decrease in actual nitrification from incubation to day 30 (Figure 1d). The Tithonia diversifolia treatment had the highest actual nitrification of $23.26 \%$, and the Senna siamea treatment had the lowest actual nitrification of $12.36 \%$ (Figure 2d). Actual nitrification was significantly correlated with plant height $(r=-0.518)$ and the number of leaves ( $r=-0.612$ ) (Table 3).

\subsection{Plant Growth}

The analysis of the sweet corn crop yields is presented in Table 4. Plant height was not significantly different in any treatment (Table 4). The highest plant height was Tithonia diversifolia treatment $(133 \mathrm{~cm})$, whereas the lowest plant was found in the Albizia falcataria $(124 \mathrm{~cm}$ ) (Table 2). The number of leaves of the sweet corn was not significant for the treatments (Table 4). 
The highest number of leaves was found in the Senna siamea treatment (12), and the lowest was in the Albizia falcataria and Tithonia diversifolia (10). Plant dry weight was significant $(p<0.01)$ (Table 4), the highest was found in the Tithonia diversifolia treatment (27.49 g), whereas the lowest was Gliricidia maculata treatment $(22.89 \mathrm{~g})$. Plant height significantly correlated with organic $C$ by 0.754 , total $N$ by 0.744 , and the number of leaves by 0.880 . The number of leaves significantly correlated with organic $C(r=0.734)$ and total N ( $r=0.738)$ (Table 5).

\subsection{Organic C, Total N, C/N Ratio, and Soil pH}

Soil $\mathrm{pH}$ values were significantly different in all treatments, whereas the values of organic $\mathrm{C}$, total $\mathrm{N}$, and $\mathrm{C} / \mathrm{N}$ ratio were not significantly different in all treatments (Table 2). The analysis of organic $\mathrm{C}$, total $\mathrm{N}, \mathrm{C} / \mathrm{N}$ ratio, and soil $\mathrm{pH}$ are presented in Table 5 . Table 5 shows that the highest of organic C is Senna siamea treatment (2.26\%) and the lowest is Albizia falcataria treatment (1.48\%). The highest total $\mathrm{N}$ value is found in Albizia falcataria (0.25\%), and the lowest is in the control treatment $(0.21 \%)$. The highest $\mathrm{C} / \mathrm{N}$ ratio is found in Senna siamea (13.14\%), and the lowest is in Albizia falcataria $(7.78 \%)$. The highest soil $\mathrm{pH}$ value is in Tithonia diversifolia (7.66), and the lowest is in Senna siamea (7.43).

\section{Discussion}

Tithonia diversifolia can inhibit nitrification because it has a high actual nitrification value (Figure $2 \mathrm{~d}$ ) and is a low-quality litter type (Table 1). Organic matter quality was correlated with nitrification (Ryals et al., 2014), and organic matter quality is often mediated by tree species (Kelly et al., 2011). The litter quality factor that most influenced the release of ammonium and the formation of soil nitrate (nitrification) was the (lignin + polyphenol)/N ratio, not lignin content, polyphenols, or the $\mathrm{C} / \mathrm{N}$ ratio (Ma et al., 2016). Based on this result, the (lignin + polyphenol)/N ratio of Tithonia diversifolia indicates that it is a low-quality litter, whereas the Gliricidia maculata, Albizia falcataria, and Senna siamea are highquality litter types. Tithonia diversifolia is one of the main sources of soil organic matter, which improves the physical and chemical properties of the soil. Organic matter can provide complete nutrients, including both macro and microelements, although the amount is relatively low, so in practice, it still has to be balanced with the use of inorganic fertilizers. Soil with organic matter can also bind and store nutrients (Mahmood et al., 2017). High-quality litter is litter that has a $\mathrm{C} / \mathrm{N}$ ratio of $<20$ or a (lignin + polyphenol) $/ \mathrm{N}$ ratio of $<10$. High-quality litter should have a lignin content of $<15 \%$ and polyphenols of $<3 \%$ so that it decomposes more quickly and frees ammonium for plants (Rahman et al., 2013).

Ammonium concentration kept decreasing, for example, at $0-6$ days (Figure 1a). This indicates that the concentration of ammonium in the soil will continue to decrease over time because of plant use, microbial immobilization, and nitrification. Ammonium is utilized by plants and changes into other compounds because of the decrease in ammonium concentration (Hachiya \& Sakakibara, 2017). Ammonium concentrations also increase, for example, in the Senna siamea treatment at 6-12 days, because ammonium, which is originally immobilized by microbes, will experience mineralization and thus make ammonium available again in the soil. High ammonium concentrations can also be caused by immobilization not yet occurring as a whole (Roviqowati et al., 2014). Figure 2a, the overall average for the highest ammonium concentrations was found in the Gliricidia maculata treatment and the lowest was in the Albizia falcataria treatment. The high concentration of ammonium in the soils is caused by Gliricidia maculata and other highquality litter types that decomposes quickly. Faster decomposition occurred when lignin + polyphenols get smaller because lignin and polyphenols can bind $\mathrm{N}$ to litter (Rahman et al., 2013).

Table 4. Plant growth parameters with various litter treatments for 30 days

\begin{tabular}{lccc}
\hline \multicolumn{1}{c}{ Treatment } & Plant height $(\mathrm{cm})$ & Number of leaves (leaves) & Plant dry weight (g) \\
\hline Control & 126 & 11 & 23.46 \\
Gliricidia maculata & 132 & 11 & 22.89 \\
Albizia falcataria & 124 & 10 & 25.00 \\
Senna siamea & 132 & 12 & 25.93 \\
Tithonia diversifolia & 133 & 10 & 27.49 \\
\hline
\end{tabular}

Table 5. Organic $\mathrm{C}$, total $\mathrm{N}, \mathrm{C} / \mathrm{N}$ ratio, and $\mathrm{pH} \mathrm{H}_{2} \mathrm{O}$ of soil with various litter treatments for 30 days

\begin{tabular}{lcccc}
\hline \multicolumn{1}{c}{ Treatment } & Organic C(\%) & Total N (\%) & $\mathrm{C} / \mathrm{N}(\%)$ & $\mathrm{pH} \mathrm{H} \mathrm{H}_{2} \mathrm{O}$ \\
\hline Control & 1.55 & 0.21 & 11.61 & 7.61 \\
Gliricidia maculata & 1.97 & 0.23 & 10.75 & 7.52 \\
Albizia falcataria & 1.48 & 0.25 & 7.78 & 7.45 \\
Senna siamea & 2.26 & 0.23 & 13.14 & 7.43 \\
Tithonia diversifolia & 1.79 & 0.22 & 9.72 & 7.66 \\
\hline
\end{tabular}




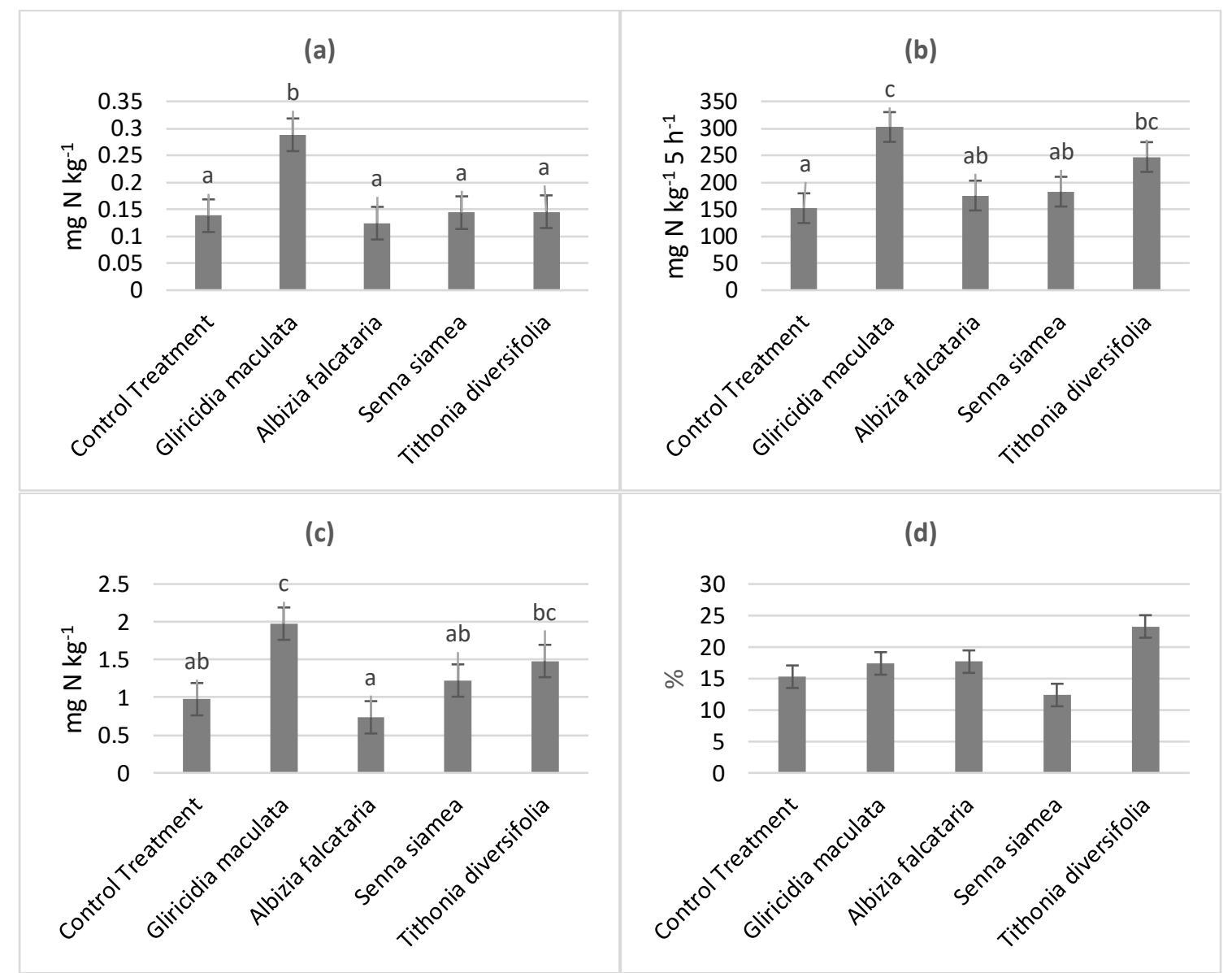

Figure 2. Average concentration of (a) ammonium, (b) potential nitrification, (c) nitrate, and (d) actual nitrification for 30 days. Bar lines indicate standard error. Bar followed by the same letter is not significantly different at $\alpha=0.05$

Ammonium concentration has a positive correlation with actual nitrification, which means that the higher ammonium concentration will be followed by actual nitrification. High actual nitrification means that the efficiency of nitrogen utilization is also high. It is because the actual nitrification is obtained from the ammonium/N mineral ratio (ammonium + nitrate). A high ammonium $/ \mathrm{N}$ mineral ratio means that the ammonification process is higher than the nitrification process in the soil (Wang et al., 2018). The Gliricidia maculata treatment has the highest potential nitrification, and the control treatment has the lowest (Figure 1b). Gliricidia maculata is a high-quality litter type with a low $\mathrm{C} / \mathrm{N}$ ratio. This causes an imbalance of ammonium mineralization with ammonium immobilization, and so the potential nitrification is high (Wang et al., 2018). Potential nitrification increased because of the availability of ammonium, which is not used by plants and microorganisms. The potential nitrification in the control treatment is supported by the low concentration of ammonium.

Nitrate concentrations increased owing to high potential nitrification. This is reinforced by the correlation between nitrate concentration and potential nitrification $(r=0.516)$ (Table 3). The formation of nitrates is inseparable from the nitrification process (Sanders \& Laanbroek, 2018). Nitrate concentration also correlates with actual nitrification, with $r=$ -0.567 (Table 3). This means that the nitrate concentration is inversely proportional to the actual nitrification. High nitrate concentrations cause low nitrogen utilization efficiency because most of the ammonium has been deformed to nitrate. Nitrate synthesis will continue to increase along with the availability of the ammonium substrate in the soil (Hachiya \& Sakakibara, 2017). Ammonium is abundant but not balanced against the absorption of plant nitrogen needs at the same time, so there is residual ammonium that changes into nitrate (Hachiya \& Sakakibara, 2017). The data in Figure $2 c$ are identical to the ammonium data in Figure $2 a$, indicating that nitrate concentration is also influenced by ammonium concentration.

The actual nitrification ratio is the ammonium $/ \mathrm{N}$ concentration of minerals in the soil. The actual nitrification is obtained by calculating the ratio of the concentration of ammonium to the amount of $\mathrm{N}$ minerals. As can be seen in Figure $2 d$, the Tithonia diversifolia litter has the highest actual nitrification, indicating that the Tithonia diversifolia litter has the highest nitrogen utilization efficiency when compared to other litter types and has low nitrification, because nitrogen can be maintained in the form of ammonium. The higher the ammonium/ $\mathrm{N}$ mineral ratio, the higher the proportion of ammonification processes compared to nitrification in the soil or the higher the efficiency of nitrogen utilization in the soil (Purwanto \& Supriyadi, 2014). It means that Tithonia diversifolia treatment has the highest nitrogen utilization efficiency.

Plant height is a plant size often observed as an indicator of growth as well as a parameter to measure environmental influences or treatments applied because plant height is the 
most easily measured growth measure (Wardhani \& Kusumastuti, 2014). Sweet corn plants with the Tithonia diversifolia litter treatment have the best plant growth compared to those with other treatments. Tithonia diversifolia litter also has the highest actual nitrification, indicating that the litter has the highest utilization of $\mathrm{N}$ efficiency. This proves that the efficiency of nitrogen utilization can increase crop yields. Plant dry weight shows the effect of water content and nutrients on plant metabolism and growth. Rapid nutrient uptake occurs in the vegetative phase of plants, wherein the $\mathrm{N}$ element reaches the points where leaves, stems, and male flowers have grown and then fills the seeds (Ciampitti et al., 2013). Plant height and the number of leaves correlated with organic $C$ and total $\mathrm{N}$. This means that plant height and the number of leaves are influenced by organic $\mathrm{C}$ and total $\mathrm{N}$. Organic $\mathrm{C}$ and total $\mathrm{N}$ describe the state of soil organic matter. The organic material content is in line with organic C. Soil organic carbon (SOC) and total $\mathrm{N}$ are important soil components for agricultural production. Soil quality is related to the total amount of SOC and total $\mathrm{N}$ sequestered in the soil (Xue \& An, 2018). Organic matter increases soil fertility and exchangeable nutrients that are slowly provided to plants (Aziz et al., 2017). Organic C and low total $\mathrm{N}$ cause low availability of $\mathrm{N}$ for plants, which consequently inhibits plant growth (Mahmood et al., 2017). Studies have shown that nitrification rates in soils are dependent on the nitrifying organisms and various environmental factors such as $\mathrm{pH}$ and substrate concentrations (Le et al., 2019) and may be significantly affected by nitrogen fertilizer management (Fan et al., 2011).

\section{Conclusion}

The Tithonia diversifolia litter treatment was more optimal for inhibiting nitrification in Vertisols compared to Gliricidia maculata, Albizia falcataria, and Senna siamea. Sweet corn plants treated with the Tithonia diversifolia litter had the best plant growth compared to the other treatments because the Tithonia diversifolia litter had the highest actual nitrification value, indicating that Tithonia diversifolia litter had the highest $\mathrm{N}$ utilization efficiency. The decomposition process of Tithonia diversifolia is slow, so the supply of ammonium is slow and the microorganisms can live longer to compete with nitrifying bacteria; therefore, nitrification is slowed down. For further research, we suggest direct application in the field without equalizing the size of the litter.

\section{Declaration of Competing Interest}

The authors declare no competing financial or personal interests that may appear and influence the work reported in this paper.

\section{References}

Aziz, M. A., Hazra, F., Salma, S., \& Nursyamsi, D. (2017). Soil Chemical Characteristics of Organic and Conventional Agriculture. Journal of Tropical Soils, 21(1), 19-25. https://doi.org/10.5400/jts.2016.v21i1.19-25

Ciampitti, I. A., Camberato, J. J., Murrell, S. T., \& Vyn, T. J. (2013). Maize Nutrient Accumulation and Partitioning in Response to Plant Density and Nitrogen Rate: I.
Macronutrients. Agronomy Journal, 105(3), 783-795. https://doi.org/10.2134/agronj2012.0467

Dolinšek, J., Lagkouvardos, I., Wanek, W., Wagner, M., \& Daims, H. (2013). Interactions of Nitrifying Bacteria and Heterotrophs: Identification of a Micavibrio-Like Putative Predator of Nitrospira spp. Applied and Environmental Microbiology, 79(6), 2027-2037. https://doi.org/10.1128/AEM.03408-12

Dudek, M., Waroszewski, J., Kabała, C., \& Łabaz, B. (2019). Vertisols properties and classification in relation to parent material differentiation near Strzelin (SW Poland). Soil Science Annual, 70(2), 158-169. https://doi.org/10.2478/ssa-2019-0014

Faeflen, S. J., Li, S., Xin, X., Wright, A. L., \& Jiang, X. (2016). Autotrophic and Heterotrophic Nitrification in a Highly Acidic Subtropical Pine Forest Soil. Pedosphere, 26(6), 904-910. https://doi.org/10.1016/S10020160(15)60095-9

Fan, F., Yang, Q., Li, Z., Wei, D., Cui, X. a., \& Liang, Y. (2011). Impacts of Organic and Inorganic Fertilizers on Nitrification in a Cold Climate Soil are Linked to the Bacterial Ammonia Oxidizer Community. Microbial Ecology, 62(4), 982-990. https://doi.org/10.1007/s00248-011-9897-5

Gong, P., Zhang, L.-L., Wu, Z.-J., Chen, Z.-H., \& Chen, L.-J. (2013). Responses of Ammonia-Oxidizing Bacteria and Archaea in Two Agricultural Soils to Nitrification Inhibitors DCD and DMPP: A Pot Experiment. Pedosphere, 23(6), 729-739. https://doi.org/10.1016/S1002-0160(13)60065-X

Goulding, K. W. T. (2016). Soil acidification and the importance of liming agricultural soils with particular reference to the United Kingdom. Soil Use and Management, 32(3), 390-399. https://doi.org/10.1111/sum.12270

Hachiya, T., \& Sakakibara, H. (2017). Interactions between nitrate and ammonium in their uptake, allocation, assimilation, and signaling in plants. Journal of Experimental Botany, 68(10), 2501-2512. https://doi.org/10.1093/jxb/erw449

Iklima AS, R., Diansyah, G., Agussalim, A., \& Mulia, C. (2019). Analisis Kandungan N-Nitrogen (Amonia, Nitrit, Nitrat) dan Fosfat di Perairan Teluk Pandan Provinsi Lampung. Jurnal Lahan Suboptimal : Journal of Suboptimal Lands, 8(1), 57-66. https://doi.org/10.33230/JLSO.8.1.2019.377

Kelly, C. N., Schoenholtz, S. H., \& Adams, M. B. (2011). Soil properties associated with net nitrification following watershed conversion from Appalachian hardwoods to Norway spruce. Plant and Soil, 344(1), 361-376. https://doi.org/10.1007/s11104-011-0755-5

Lan, T., Han, Y., \& Cai, Z. (2017). Comparison of Gross N Transformation Rates in Two Paddy Soils Under Aerobic Condition. Pedosphere, 27(1), 112-120. https://doi.org/10.1016/S1002-0160(15)60097-2

Le, T. T. H., Fettig, J., \& Meon, G. (2019). Kinetics and simulation of nitrification at various $\mathrm{pH}$ values of a polluted river in the tropics. Ecohydrology \& 
Hydrobiology,

19(1), https://doi.org/10.1016/j.ecohyd.2018.06.006

Liu, C.-W., Sung, Y., Chen, B.-C., \& Lai, H.-Y. (2014). Effects of Nitrogen Fertilizers on the Growth and Nitrate Content of Lettuce (Lactuca sativa L.). International Journal of Environmental Research and Public Health, 11(4), 4427-4440. https://doi.org/10.3390/ijerph110404427

Ma, H.-L., Gao, R., Yin, Y.-F., \& Yang, Y.-S. (2016). Effects of leaf litter tannin on soil ammonium and nitrate content in two different forest soils of mount Wuyi, China. Toxicological \& Environmental Chemistry, 98(34), 395-409. https://doi.org/10.1080/02772248.2015.1123483

Macdonald, B. C. T., Denmead, O. T., White, I., \& Byrant, G. (2011). Gaseous Nitrogen Losses from Coastal Acid Sulfate Soils: A Short-Term Study. Pedosphere, 21(2), 197-206. https://doi.org/10.1016/S1002 0160(11)60118-5

Mahmood, F., Khan, I., Ashraf, U., Shahzad, T., Hussain, S., Shahid, M., Abid, M., \& Ullah, S. (2017). Effects of organic and inorganic manures on maize and their residual impact on soil physico-chemical properties. Journal of soil science and plant nutrition, 17, 22-32. https://doi.org/10.4067/S0718-95162017005000002

Ngibad, K. (2019). Penentuan Konsentrasi Ammonium dalam Air Sungai Pelayaran Ngelom. Medicra (Journal of Medical Laboratory Science/Technology), 2(1), 37-42. http://ojs.umsida.ac.id/index.php/medicra/article/vie $w / 2071$

Nishizawa, K., Tatsumi, S., Kitagawa, R., \& Mori, A. S. (2016). Deer herbivory affects the functional diversity of forest floor plants via changes in competition-mediated assembly rules. Ecological Research, 31(4), 569-578. https://doi.org/10.1007/s11284-016-1367-6

Norton, J., \& Ouyang, Y. (2019). Controls and Adaptive Management of Nitrification in Agricultural Soils [Review]. Frontiers in Microbiology, 10(1931). https://doi.org/10.3389/fmicb.2019.01931

Purwanto, \& Supriyadi. (2014). Biologi Tanah Kajian Pengelolaan Tanah Selaras Alam. Pohon Cahaya. ISBN: 978-602-1542-86-6.

Purwanto, P., Hartati, S., \& Istiqomah, S. (2014). Pengaruh kualitas dan dosis seresah terhadap potensial nitrifikasi tanah dan hasil jagung manis. Sains TanahJournal of Soil Science and Agroclimatology, 11(1), 1120. https://doi.org/10.15608\%2Fstjssa.v11i1.204

Rahman, M. M., Tsukamoto, J., Rahman, M. M., Yoneyama, A., \& Mostafa, K. M. (2013). Lignin and its effects on litter decomposition in forest ecosystems. Chemistry and Ecology, 29(6), 540-553. https://doi.org/10.1080/02757540.2013.790380

Rajamuddin, U. A., Lopulisa, C., Husni, H., \& Nathan, M. (2013). Mineralogy and Micromorphology Characteristic of Vertisol Lying on Limestone Parent Rocks at Jeneponto District of South Sulawesi Province, Indonesia. International Journal of Agriculture System, 1(2), 92-97. http://pasca.unhas.ac.id/ojs/index.php/ijas/article/vi ew/9
Ransom, C. J., Jolley, V. D., Blair, T. A., Sutton, L. E., \& Hopkins, B. G. (2020). Nitrogen release rates from slow- and controlled-release fertilizers influenced by placement and temperature. PLOS ONE, 15(6), e0234544. https://doi.org/10.1371/journal.pone.0234544

Roviqowati, F., Purwanto, P., \& Hartati, S. (2014). Dinamika NMineral Tanah Vertisols pada Berbagai Kombinasi Kualitas Seresah serta Serapan N Jagung Manis [litter quality; $\mathrm{NH4+}$ and NO3- dynamics; sweet maize $\mathrm{N}$ uptake; Vertisols N-Mineral]. Sains Tanah - Journal of Soil Science and Agroclimatology, 11(1). https://doi.org/10.15608\%2Fstjssa.v11i1.206

Ruser, R., \& Schulz, R. (2015). The effect of nitrification inhibitors on the nitrous oxide (N2O) release from agricultural soils - a review. Journal of Plant Nutrition and Soil Science, 178(2), 171-188. https://doi.org/10.1002/jpln.201400251

Ryals, R., Kaiser, M., Torn, M. S., Berhe, A. A., \& Silver, W. L. (2014). Impacts of organic matter amendments on carbon and nitrogen dynamics in grassland soils. Soil Biology and Biochemistry, 68, 52-61. https://doi.org/10.1016/j.soilbio.2013.09.011

Sanders, T., \& Laanbroek, H. J. (2018). The distribution of sediment and water column nitrification potential in the hyper-turbid Ems estuary. Aquatic Sciences, 80(4), 33. https://doi.org/10.1007/s00027-018-0584-1

Scherer, H., Feils, E., \& Beuters, P. (2014). Ammonium fixation and release by clay minerals as influenced by potassium. Plant, Soil and Environment, 60(7), 325331. https://doi.org/10.17221/202/2014-PSE

Sofyan, E. T., Machfud, Y., Yeni, H., \& Herdiansyah, G. (2019). Absorption of N, P and K Nutrients of Sweet Corn Plants (Zea Mays Saccharata Sturt) Due to the Application of Urea, Sp-36, Kcl Fertilizers and Biofertilizer on Fluventic Eutrudepts from Jatinangor. Jurnal Agrotek Indonesia (Indonesian Journal of Agrotech), 4(1). https://doi.org/10.33661/jai.v4i1.1690

Tabri, F., Aqil, M., \& Efendi, R. (2018). Uji aplikasi berbagai tingkat dosis pupuk ZA terhadap produktivitas dan mutu jagung. 2018, 4(1), 15. https://doi.org/10.26858/ijfs.v4i1.6012

Urakawa, R., Ohte, N., Shibata, H., Isobe, K., Tateno, R., Oda, T., Hishi, T., Fukushima, K., Inagaki, Y., Hirai, K., Oyanagi, N., Nakata, M., Toda, H., Kenta, T., Kuroiwa, M., Watanabe, T., Fukuzawa, K., Tokuchi, N., Ugawa, S., Enoki, T., Nakanishi, A., Saigusa, N., Yamao, Y., \& Kotani, A. (2016). Factors contributing to soil nitrogen mineralization and nitrification rates of forest soils in the Japanese archipelago. Forest Ecology and Management, 361, 382-396. https://doi.org/10.1016/j.foreco.2015.11.033

Veresoglou, S. D. (2012). Arbuscular Mycorrhiza Prevents Suppression of Actual Nitrification Rates in the (Myco-) Rhizosphere of Plantago lanceolata. Pedosphere, 22(2), 225-229. https://doi.org/10.1016/S10020160(12)60009-5

Wang, C., Wang, N., Zhu, J., Liu, Y., Xu, X., Niu, S., Yu, G., Han, $X ., \& H e, N$. (2018). Soil gross $N$ ammonification and 
nitrification from tropical to temperate forests in eastern China. Functional Ecology, 32(1), 83-94. https://doi.org/10.1111/1365-2435.13024

Ward, B. B. (2011). Chapter thirteen - Measurement and Distribution of Nitrification Rates in the Oceans. In M. G. Klotz (Ed.), Methods in Enzymology (Vol. 486, pp. 307-323). Academic

Press. https://doi.org/10.1016/B978-0-12-381294-0.000134

Wardhani, W. S., \& Kusumastuti, P. (2014). DESCRIBING THE HEIGHT GROWTH OF CORN USING LOGISTIC AND GOMPERTZ MODEL. 2014, 35(3), 5. https://doi.org/10.17503/agrivita.v35i3.358

Wati, A. S. P., Pambayun, L. P. S., Purwanto, Hartati, S., \& Supriyadi. (2020). Effectiveness of Nitrification Inhibition through Addition of Local Litter to Corn Plants in Andisols. Modern Applied Science. https://doi.org/10.5539/mas.v14n7p120

Xue, Z., \& An, S. (2018). Changes in Soil Organic Carbon and Total Nitrogen at a Small Watershed Scale as the
Result of Land Use Conversion on the Loess Plateau. Sustainability, 10(12), https://doi.org/10.3390/su10124757

Yao, H., Gao, Y., Nicol, G. W., Campbell, C. D., Prosser, J. I., Zhang, L., Han, W., \& Singh, B. K. (2011). Links between Ammonia Oxidizer Community Structure, Abundance, and Nitrification Potential in Acidic Soils. Applied and Environmental Microbiology, 77(13), 4618-4625. https://doi.org/10.1128/AEM.00136-11

Yu, W.-T., Xu, Y.-G., Bi, M.-L., Ma, Q., \& Zhou, H. (2010). Activity and Composition of Ammonia-Oxidizing Bacteria in an Aquic Brown Soil as Influenced by Land Use and Fertilization. Pedosphere, 20(6), 789-798. https://doi.org/10.1016/S1002-0160(10)60069-0

Zhang, X., Wang, Q., Xu, J., Gilliam, F. S., Tremblay, N., \& Li, C. (2015). In Situ Nitrogen Mineralization, Nitrification, and Ammonia Volatilization in Maize Field Fertilized with Urea in Huanghuaihai Region of Northern China. PLOS ONE, 10(1), e0115649. https://doi.org/10.1371/journal.pone.0115649 